\title{
Leaching potential of the herbicide mixture 2,4-D + picloram
}

\author{
Potencial de lixiviação da mistura dos herbicidas 2,4-D + picloram
}

\begin{abstract}
Jéssica Ferreira Lourenço Leal'; Vanessa Francieli Vital Silva²; Amanda dos Santos Souza ${ }^{3}$; Ana Claudia Langaro ${ }^{4}$; Marcelo Pereira Sampaio ${ }^{5}$; Caio Victor Lopes Pereira ${ }^{6}$; Camila Ferreira de Pinho ${ }^{7}$

${ }^{1}$ Mestre, Universidade Federal Rural do Rio de Janeiro, jessica-agroleal@hotmail.com

${ }^{2}$ Mestre, Universidade Estadual de Maringá. Maringá (UEM), vfvitalsilva@gmail.com

${ }^{3}$ Mestre, Universidade Federal Rural do Rio de Janeiro, amanda.engagronoma@gmail.com

${ }^{4}$ Autor para correspondência. Doutora, Universidade Federal Rural do Rio de Janeiro, Instituto de Engenharia. Rodovia BR 465 - km 7. Seropédica - RJ. CEP: 23890-000. Endereço eletrônico: langaro.ac@gmail.com

${ }^{5}$ Engenheiro Agrônomo, Universidade Federal Rural do Rio de Janeiro, marsampaio08@gmail.com

${ }^{6}$ Graduando em Engenharia Agrícola e Ambiental, Universidade Federal Rural do Rio de Janeiro, kayovic25@hotmail.com

${ }^{7}$ Doutora, Universidade Federal Rural do Rio de Janeiro, camilafepi@ufrrj.br
\end{abstract}

Recebido em: 22-12-2018; Aceito em: 09-03-2020

\begin{abstract}
Weed control strategies are fundamental to ensure pasture productivity and quality in Brazil. However, care must be taken in the use of long residual herbicides, which can increase the risk of leaching. From this context, the present study evaluates the leaching potential of the commercial mixture of herbicides 2,4-D + picloram. Leaching columns filled with loam-clay-sandy soil were used. The columns were $0.6 \mathrm{~m}$ in length and $0.2 \mathrm{~m}$ in diameter. The experimental design was randomized blocks with eight replications. Treatments were arranged in a $5 \times 2$ factorial scheme, in which factor A corresponds to herbicide doses $\left(0,1,2,3\right.$ and, $\left.4 \mathrm{~L} \mathrm{ha}^{-1}\right)$ and factor $\mathrm{B}$ corresponds to the position of herbicides in the columns $(0-30 \mathrm{~cm}$ and $30-60 \mathrm{~cm}$ depth). After herbicide application, weekly rainfall of $60 \mathrm{~mm}$ was simulated for four weeks at the top of the columns. The columns were sectioned vertically giving rise to two section, which were separated into two portions $(0-30 \mathrm{~cm}$ and $30-60 \mathrm{~cm})$. Then, cucumber was sown as a bioindicator in the $0-30 \mathrm{~cm}$ and $30-60 \mathrm{~cm}$ layers. At 45 days after sowing, the following parameters were determined: chlorophyll a fluorescence transient, shoot length, root length, and total dry weight of plants. Both the chlorophyll fluorescence data and the biometric data of the bioindicator plant showed the presence of the commercial mixture only in the first $30 \mathrm{~cm}$ of depth. It is concluded that 2,4-D + picloram remained in the $0-30 \mathrm{~cm}$ deep layer of the loam-clay-sandy soil after $240 \mathrm{~mm}$ rainfall.
\end{abstract}

Additional keywords: auxin mimics; bioindicators; carryover; Cucumis sativus.

\begin{abstract}
Resumo
Para assegurar a produtividade e a qualidade das pastagens no Brasil é fundamental a adoção de estratégias de controle da comunidade de plantas daninhas. No entanto, cuidados devem ser tomados quanto ao uso de herbicidas com longo período residual, que pode aumentar o risco de lixiviação. A partir deste contexto, o objetivo deste trabalho foi avaliar o potencial de lixiviação da mistura comercial dos herbicidas 2,4-D+picloram. Foram utilizadas colunas de lixiviação, com 0,6 m de comprimento e 0,2 $\mathrm{m}$ de diâmetro, preenchidas com solo de textura francoargilo-arenosa. O delineamento experimental foi em blocos casualizados, com 8 repetições. Os tratamentos foram dispostos em esquema fatorial $5 \times 2$, sendo o fator $A$ as doses dos herbicidas $\left(0,1,2,3\right.$ e $\left.4 \mathrm{~L} \mathrm{ha}^{-1}\right)$ e o fator $B$ as posições na coluna (0-30 cm e 30-60 cm de profundidade). Após a aplicação do herbicida, simulou-se a precipitação de $60 \mathrm{~mm}$ semanais, durante quatro semanas, no topo das colunas. As colunas foram seccionadas verticalmente originando duas canaleta, as quais foram separadas em duas porções, semeando-se pepino como bioindicadora nas camadas de 0-30 cm e 30-60 cm. Determinou-se parâmetros de transiente da fluorescência da clorofila a, comprimento da parte aérea, comprimento das raízes e massa seca total das plantas 45 dias após a semeadura. Tanto os dados de fluorescência da clorofila a quanto os dados biométricos da planta bioindicadora evidenciaram a presença da mistura comercial apenas nos primeiros $30 \mathrm{~cm}$ de profundidade. Conclui-se que 0 2,4-D+piclorampermaneceu na camada de $0-30 \mathrm{~cm}$ de profundidade do solo franco-argilo-arenoso após $240 \mathrm{~mm}$ de precipitação.
\end{abstract}

Palavras-chave adicionais: bioindicadoras; carryover; Cucumis sativus; mimetizadores de auxina.

\section{Introduction}

Livestock is one of the most important activities in Brazilian agribusiness, influencing gross domestic product (GDP) and job generation. However, a large part of the pastures in the country are in some stage of degradation, with weed infestations being commonly noticed, which results in low quality products and yield loss in these areas (Pellegrini et al., 2010; Mendes et al., 2016). 
There are different management possibilities to minimize weed interference in pasture areas. Chemical management is highlighted in this context due to the ease of use of its main tool, herbicides. Among the herbicides registered for pasture, the 2,4-D + picloram mixture is one of the most used. These two molecules have the mechanism of action of auxin mimics (Franco et al., 2014; Santos et al., 2015).

Physicochemical characteristics of picloram include a $2.3 \mathrm{pKa}$ (electrolytic dissociation constant). Therefore, this herbicide predominates in its dissociated form, which favors low sorption in most Brazilian soils (Senseman, 2007). Moreover, it is very soluble in water, which increases its leaching potential (Chen et al., 2010; Maciel et al., 2013; Marco-Brown et al., 2014). This may cause groundwater contamination and prevent rotation of crops sensitive to synthetic auxins.

Regarding environmental dynamics, despite being potentially mobile in the soil, 2,4-D presents rapid degradation, mainly by microorganisms, which minimizes its leaching. The half-life of 2,4-D is approximately 10 days (Senseman, 2007; Peres-Oliveira et al., 2017), but drift problems are commonly associated with this herbicide.

Molecules that have long persistence in the soil, such as picloram, can lead to a phenomenon called carryover, in which its residues, in addition to affecting sensitive successive crops, also increase the risks of leaching and groundwater contamination due to the permanence of the product in the soil for a longer period of time than desired (Franco et al., 2015).

Bioassays with indicator plants are used to identify the activity of herbicidal molecules in the soil (Peres-Oliveira et al., 2017). Cucumber (Cucumis sativus L.) is a bioindicator of contamination caused by auxinic herbicides, and shows easy cultivation, fast growth, and high sensitivity to products from this group (Santos et al., 2015). Symptoms of intoxication such as epinasty, shortening of internerve tissue, growth arrest, among others, are easily identified in cucumbers when exposed to this type of residues in the soil (Santos et al., 2015; Christoffoleti et al., 2015).

In this context, the present study evaluates leaching after application of the commercial mixture of herbicides 2,4-D + picloram, using cucumber plants as bioindicators.

\section{Material and methods}

The experiment was conducted in a greenhouse, in a randomized block design with eight replications arranged in a 5x2 factorial scheme, with factor $A$ corresponding to doses $\left(1,2,3\right.$, and $\left.4 \mathrm{~L} \mathrm{ha}^{-1}\right)$ of the commercial mixture 2,4-D (240 g a.e. $\left.\mathrm{L}^{-1}\right)+$ picloram $\left(64 \mathrm{~g}\right.$ a.e. $\mathrm{L}^{-1}$ ) (commercial mixture-Tordon ${ }^{\circledR}$ ) plus the control without application, and factor B corresponding to the position of herbicides in the columns $(0-30 \mathrm{~cm}$ and 30-60 cm depth).

Experimental units were leaching columns made of PVC, with $0.60 \mathrm{~m}$ in length and $0.20 \mathrm{~m}$ in diameter. The columns were filled using sieved Latosol without history of herbicide use. Chemical and physical characteristics are shown in Table 1. Screens were placed in the basal portion of the columns to retain the soil and allow water to drain, since the tubes were kept in a vertical position, inside polyethylene pots filled with gravel. After being filled with the soil samples, they were saturated with water.

Table 1 - Chemical and granulometric analysis of the soil used in the experiment.

\begin{tabular}{|c|c|c|c|c|c|c|c|c|}
\hline $\mathrm{pH}$ & $\mathrm{Al}^{3+}$ & $\left(\mathrm{H}^{+}+\mathrm{Al}^{3+}\right)$ & $\begin{array}{c}\mathrm{Ca}^{2+} \\
\left(\mathrm{cmol}_{c} \mathrm{dm}\right.\end{array}$ & $\mathrm{Mg}^{2+}$ & $\mathrm{K}^{+}$ & $\begin{array}{c}\mathrm{P} \\
\left(\mathrm{mg} \mathrm{dm}^{-3}\right)\end{array}$ & V & $m$ \\
\hline 5.7 & 0.4 & 4.4 & 3.0 & 1.4 & 70.0 & 48.0 & 57.0 & 7.8 \\
\hline \multicolumn{2}{|c|}{ Coarsesand } & -- (dag & $\begin{array}{l}\text { hinsand } \\
\left.\mathrm{g}^{-1}\right) \text {----. }\end{array}$ & Silt & Clay & \multirow{2}{*}{\multicolumn{3}{|c|}{$\begin{array}{c}\text { Textural class } \\
\text { Sandy Clay Loam }\end{array}$}} \\
\hline \multicolumn{2}{|c|}{55} & & 18 & 4 & 23 & & & \\
\hline
\end{tabular}

The herbicide mixture was applied on the surface of columns using a $\mathrm{CO}_{2}$-pressurized backpack sprayer equipped with four TeeJet XR110020 flat-fan nozzles (TeeJet Technologies), which delivered $150 \mathrm{~L}$ ha- 1 of spray solution at 2.8 bar.

All columns received a weekly rainfall of $60 \mathrm{~mm}$, totaling $240 \mathrm{~mm}$ of rainfall until the opening of columns. At 32 days after application (DAA) of the commercial mixture of herbicides 2,4-D + picloram, the columns were opened vertically, giving rise to two section and, consequently, eight replications of each treatment. The soil inside the section was divided with a plastic sheet into two parts: the first $(0-30 \mathrm{~cm})$ and the second portion $(30-60 \mathrm{~cm}$ ) of the column. Then, cucumber (Cucumis sativus L.) was sown at $0-30 \mathrm{~cm}$ and $30-60 \mathrm{~cm}$ depth, corresponding to the first and second portion of the column, respectively.

Transient chlorophyll a fluorescence was evaluated at $\mathbf{4 5}$ days after cucumber sowing using a portable fluorometer (HandyPEA, Hanstech, King's Lynn, Norkfolk, UK). The clips used for these measurements were placed on the middle third of fully expanded young leaves in the morning. Measurements were made 20 min after the leaves were adapted to the dark. Fluorescence emission was induced in an area of $4 \mathrm{~mm}$ in diameter by exposing the sample to a pulse of saturating light at an intensity of $3,000 \mu \mathrm{mol} \mathrm{m} \mathrm{m}^{-2} \mathrm{~s}^{-1}$. From the transient fluorescence curve obtained after the pulse, the intensities determined at $50 \mu \mathrm{s}$ (initial fluorescence - F0), $100 \mu \mathrm{s}, 300 \mu \mathrm{s}, 2 \mathrm{~ms}$ (FJ), $30 \mathrm{~ms}$ 
(FI), and FM (maximum fluorescence) were used to calculate the parameters established by the JIP Test (Strasser \& Strasser, 1995).

The following were also determined at 45 days after cucumber sowing: shoot length (SL), root length $(R L)$, and total dry weight (TDW) of plants. The shoot and root length of bioindicator plants were measured from the ground to the apex of shoots and roots, respectively. After collecting the plants, shoots and roots were packed together in paper bags and placed in a forced-air circulation oven at $65 \pm 5^{\circ} \mathrm{C}$ until constant weight to obtain TDW a precision balance.

Data were submitted to analysis of variance
( $p \leq 0.05$ ) and tested by polynomial regression models when significant. The choice of models was based on statistical significance ( $F$ test), adjustment of the coefficient of determination $\left(R^{2}\right)$, and biological significance of the model.

\section{Results and discussions}

There was no interaction between the herbicide dose and herbicide position in the leaching column. However, in isolation, these factors were significant for all variables evaluated (Table 2 ).

Table 2 - Means of shoot length (SL; $\mathrm{cm})$, root length (RL; $\mathrm{cm}$ ) and total dry mass (TDM; g) of cucumber plants (Cucumis sativus) grown in two positions (top and bottom) of leach columns containing soil with the commercial mixture of 2,4-D + picloram herbicides.

\begin{tabular}{llll}
\hline Depth & $\mathrm{SL}$ & $\mathrm{RL}$ & $\mathrm{TDM}$ \\
\hline $0-30 \mathrm{~cm}$ & 3.86 & 1.6 & 0.14 \\
$30-60 \mathrm{~cm}$ & $6.73^{\star}$ & $2.3^{\star}$ & $0.25^{\star}$ \\
\hline
\end{tabular}

${ }^{*}$ significant by $\mathrm{F}$ test $(\mathrm{p} \leq 0.05)$.

Cucumis sativus plants showed lower SL, RL, and TDW in the first $30 \mathrm{~cm}$ depth compared to the $30-60 \mathrm{~cm}$ depth, regardless of the applied dose. Retention of molecules of the mixture in the first centimeters of depth $(0-30 \mathrm{~cm})$ indicates that the rainfall volume of $240 \mathrm{~mm}$ during the 32 days before the opening of columns was not sufficient to leach a significant amount of the commercial mixture to depths greater than $30 \mathrm{~cm}$, which would cause toxicity to cucumber plants (Table 2). These findings contradict the predictions for auxinic herbicides such as picloram and 2,4-D, which are known as molecules with high leaching potential in different soil types (D'Antonino et al., 2009; Franceschi et al., 2015). Picloram is characterized by low sorption in soil colloids (D'Antonino et al., 2009), with a half-life of 90 days, and lasting up to 360 DAA (Santos et al., 2006). As well as picloram, 2,4-D has high solubility, $2.8 \mathrm{pKa}$, and an average Koc of $20 \mathrm{~mL} \mathrm{~g}^{-1}$ soil. Notwithstanding,2,4-D has low persistence in the soil, with a half-life of 10 days (Senseman, 2007).

The permanence of herbicides in the $0-30 \mathrm{~cm}$ layer is due to the low pKa of both herbicides associated with soil $\mathrm{pH}$ of 5.7 and loam-clay-sandy texture, indicating less adsorption of the herbicide to colloids and greater availability in the soil solution. Herbicide leaching is highly dependent on rainfall, among other characteristics (Monquero et al., 2008). Picloram was shown to persist in the first $10 \mathrm{~cm}$ of depth in clay-sandy soil (Santos et al., 2006), and leached up to depth of 32 $\mathrm{cm}$ in dystrophic Red-Yellow Latosol (Franceschi et al., 2015).

The variables SL, RL, and TDW decreased with increasing doses of the commercial mixture, regardless of the position in the column. Shoot length (SL) decreased by $29,45,61$, and $63 \%$ with the doses of 1 , 2, 3, and $4 \mathrm{~L} \mathrm{ha}^{-1}$, respectively, compared to the control (untreated) (Figure 1A). Root length $(R L)$ decreased by $35,34,70$, and $72 \%$ with the doses of $1,2,3$, and $4 \mathrm{~L} \mathrm{ha}^{-1}$ respectively, compared to the control (Figure $1 B)$. The reduction in $S L$ and $R L$ is related to the sensitivity of cucumber to auxinic herbicides (Christoffoleti et al., 2015).

Total dry weight (TDM) decreased by 24,24 , 55 , and $59 \%$ with the doses of $1,2,3$, and $4 L \mathrm{ha}^{-1}$ of the commercial mixture of herbicides $2,4-D+$ picloram, respectively, compared to the control (Figure 1C). This may be related to the action of synthetic auxins, which in addition to promoting characteristic symptoms such as leaf epinasty and growth paralysis, can disturb conducting vessels, hindering water transport and redistribution of photoassimilates (Christoffoleti et al., 2015; Peterson et al., 2016). D'Antonino et al. (2009) observed similar results, where crops sensitive to auxin-mimicking herbicides and grown in loamy-clayey soils subject to the application of herbicides belonging to this mechanism of action also had a decrease in dry weight accumulation.

In plants under stress conditions, chlorophyll a fluorescence analysis can be used to understand the mechanisms of photosynthesis and to assess changes in photosynthetic capacity by different types of stress (Strasser et al., 1995; Dayan and Zaccaro, 2012). The evaluation of fluorescence emission kinetics is a fast, simple, and non-invasive method. Although photosynthesis is not considered a primary target for auxinherbicides, it is possible to detect changes in fluorescence responses in plants treated with these herbicides (Dayan \& Zaccaro, 2012). 

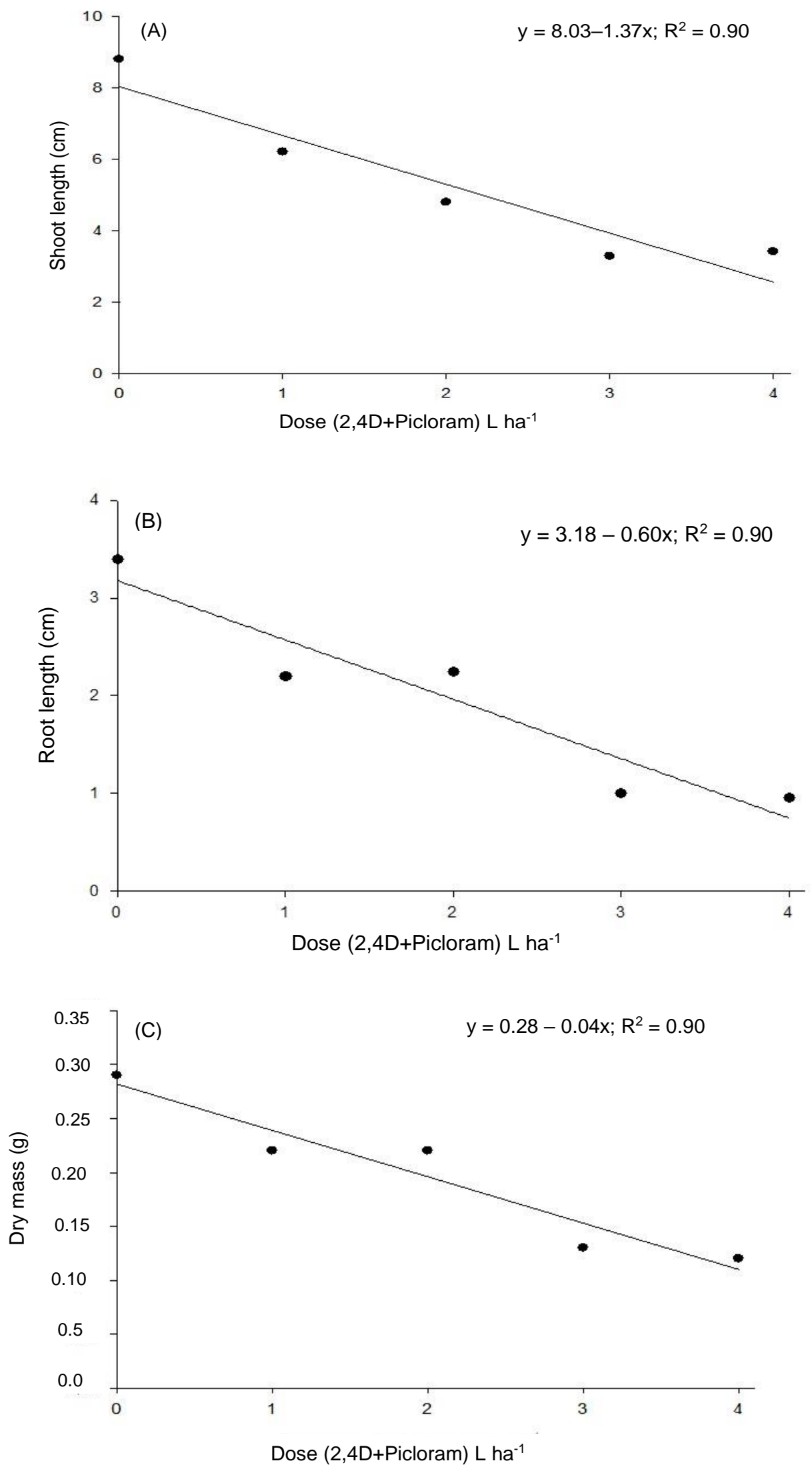

Figure 1 - Shoot length (A), root length (B) and total dry mass (C) of cucumber plants (Cucumis sativus) sown in leach columns 32 days after application of commercial mixture of herbicides 2,4-D + picloram and evaluated 45 days after sowing. 
The chlorophyll a fluorescence transient corroborate with biometric data presented previously. At the $0-30 \mathrm{~cm}$ depth (Figure $2 \mathrm{~A}$ ), reductions of $20 \%$ (doses of 1 and $2 \mathrm{~L} \mathrm{ha}^{-1}$ of the herbicide) and $40 \%$ (doses of 3 and $4 \mathrm{~L} \mathrm{ha}^{-1}$ of the herbicide) were observed in photosynthetic indexes ( $\mathrm{Pl}_{\mathrm{TOTAL}}$ and $\mathrm{Pl}_{\mathrm{ABS}}$ ). This is due to the energy conservation of the captured exciton to reduce the final electron acceptor of the intersystem (Pl $\mathrm{I}_{\mathrm{ABS}}$ ) and PSI (PI $\left.\mathrm{I}_{\mathrm{TOTAL}}\right)$. The energy absorbed by the plant during photosynthesis has three destinations that compete against each other: photochemistry (energy production and reducing power); energy dissipated in the form of heat; and fluorescence (Krause and Weis,
1991), so that any increase in the efficiency of one will decrease the performance of the others. Thus, the observed decline in the photosynthetic performance of cucumber plants in the $0-30 \mathrm{~cm}$ layer reflects an increase in energy dissipation in the form of heat $(\varphi \mathrm{D} 0$ and DIO/RC) by approximately $20 \%$ at a dose of $4 \mathrm{~L} \mathrm{ha}^{-}$ 1 . This demonstrates the inability of the plant to use this energy for photosynthesis, which may impair plant growth. Fluorescence is a potential indicator of stress and can be considered as an indicator of physiological disorders before the appearance of visible signs of stress (Oukarroum et al., 2007).
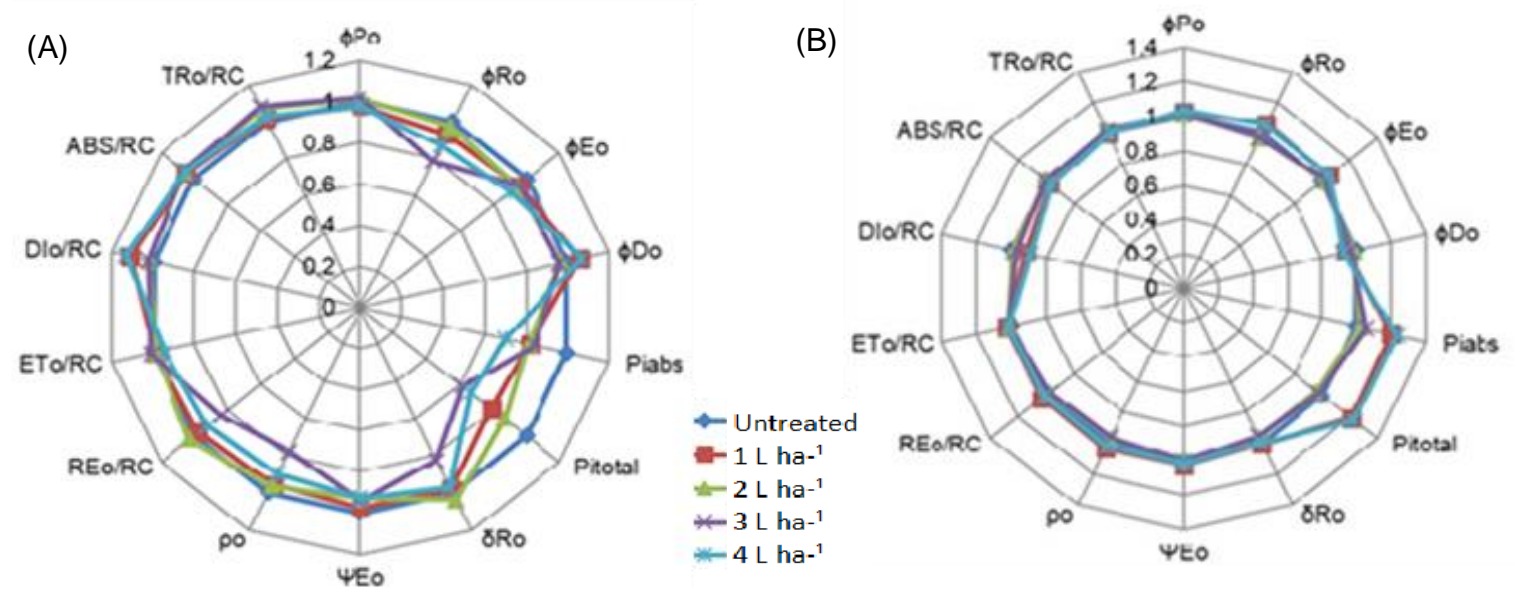

Figure 2 - Residual effect of the commercial mixture of 2,4-D + picloram herbicides on cucumber plants (Cucumis sativus) cultivated in the $0-30 \mathrm{~cm}(\mathrm{~A})$ and $30-60 \mathrm{~cm}(\mathrm{~B})$ portions of the leaching columns at 45 days after sowing, under the transient fluorescence parameters of chlorophyll $a$, obtained by the JIP test (center radar plot $=0.0$, maximum $=1.4$ ) in relation to the control - behavior pattern (full line $=1.0$ ).

At the $30-60 \mathrm{~cm}$ depth, cucumber plants grown in soil subject to the commercial mixture of herbicides 2,4-D + picloram did not differ from the control regarding transient chlorophyll a fluorescence (Figure 2B), except in the dose of 1 and $4 \mathrm{~L}^{-1}$ of the herbicide, which caused a $20 \%$ increase in photosynthetic parameters. This increase in photosynthetic performance is probably associated with plant recovery from stress, not reflecting differences in plant height and biomass, as can be seen in biometric data.

\section{Conclusion}

The commercial mixture of herbicides 2,4-D + picloram remained in the first 30 centimeters of depth of a loam-clay-sandy soil when subject to $240 \mathrm{~mm}$ rainfall.

\section{References}

Chen L, Zeng G, Zhang Y, Tang L, Huang D, Liu C, Luo $J$ (2010) Trace detection of picloram using an electrochemical immunosensor based on three-dimensional gold nanoclusters. Analytical Biochemistry 407(2):172-179.
Christoffoleti PJ, Figueiredo MRAD, Peres LEP, Nissen $S$, Gaines T (2015) Auxinic herbicides, mechanisms of action, and weed resistance: A look into recent plant science advances. Scientia Agricola 72(4):356-362.

D'Antonino L, Silva AA, Ferreira LR, Cecon PR, França AC, Silva GR (2009) Picloram leaching on red-yellow latosol and red-yellow ultisol with different $\mathrm{pH}$ values. Planta Daninha 27(3):589-600.

Dayan FE, Zaccaro MLM (2012) Chlorophyll fluorescence as a marker for herbicide mechanisms of action. PesticideBiochemistryandPhysiology102(3):189-197.

Franceschi M, Felito RA, Yamashita OM, Lorenzon J, Carvalho MAC (2015) Lixiviação do herbicida 2,4D+picloram em Latossolo Vermelho-Amarelo distrófico. Enciclopédia Biosfera (11):2151.

Franco MHR, Lemos VT, Aguiar LM, França AC, Ferreira EA, Silva DV (2015). Características fisiológicas do feijoeiro cultivado em solos após fitorremediação do picloram. Revista Brasileira de Herbicidas 14(4):315$-325$ 
Franco, MHR, França AC, Albuquerque MT, Carvalho NS, Nascimento GV (2014) Fitorremediação de solos contaminados com picloram por Urochloabrizantha. Pesquisa Agropecuária Tropical44(4): 460-467.

Krause GH, Weis E (1991) Chlorophyll fluorescence and photosynthesis: the basics. Annual Review of Plant Biology 42(1):313-349.

Maciel GM, de Souza CGM, Araújo CAV, Bona E, Haminiuk CWI, Castoldi R, Peralta RM (2013) Biosorption of herbicide picloram from aqueous solutions by live and heat-treated biomasses of Ganoderma lucidum (Curtis) P. Karst and Trametes sp Chemical Engineering Journal 215:331-338.

Marco-Brown J L, Areco MM, Sánchez RMT, Santos Afonso M (2014) Adsorption of picloram herbicide on montmorillonite: kinetic and equilibrium studies. Colloids and surfaces A: Physicochemical and Engineering Aspects 449:121-128.

Mendes RR, Biffe DF, Constantin J, Oliveira JrRS, Rosa ÊL, Cuba ALF, Baladeli RB (2016) Controle de amarelinho (Tecomastans) em pastagem com aplicações localizadas de herbicidas Revista Brasileira de Herbicidas 15(4):303-312.

Monquero PA, Amaral LR, Binha DP, Silva AC, Silva PV (2008) Potencial de lixiviação de herbicidas no solo submetidos a diferentes simulações de precipitação. Planta Daninha26(2):403-409

Oukarroum A, El Madidi S, Schansker G, Strasser RJ (2007) Sondagem das respostas de cultivares de cevada (Hordeumvulgare L.) por fluorescência de clorofila a OLKJIP sob estresse hídrico e re-irrigação. Botânica Ambiental e Experimental 60 (3):438-446.
Pellegrini LGD, Nabinger C, Neumann M, Carvalho PCDF, Crancio LA (2010) Produção de forragem e dinâmica de uma pastagem natural submetida a diferentes métodos de controle de espécies indesejáveis e à adubação. Brazilian Journal of Animal Science (11):2380-2388.

Peres-Oliveira MA, Bonfim-Silva EM, da Silva VM, da Silva TJA, de Freitas Sousa HH (2017) Soybean as bioindicadorof residual effectof 2,4-D herbicide in an oxisol from the Brazilian cerrado. African Journal of Agricultural Research 12(1):35-41.

Peterson MA, Mcmaster AS, Riechers DE, Skelton J, Stahlman PW (2016) 2,4-D Past, Present, and Future: A Review Weed Technology 30:303-345.

Santos DP, Braga RR, Guimarães FAR, de Jesus Passos ABR, Silva DV, dos Santos JB, Nery M C (2015) Determinação de espécies bioindicadoras de resíduos de herbicidas auxínicos. Ceres 60(3): 354-362.

Santos MV, Freitas FCL, Ferreira FA, Viana RG, Tuffi Santos LD, Fonseca DM (2006) Eficácia e persistência no solo de herbicidas utilizados em pastagem. Planta Daninha 24(2):391-398.

Senseman SA (2007) Herbicide handbook. Lawrence: Weed Science Society of America. 459p.

Strasser BJ, Strasser RJ (1995) Measuring fast fluorescence transients to address environmental question: the JIP test. in Mathis, P. (ed.) Photosynthesis: From Light to Biosphere, Kluwer Academic Publisher. p. 977-980 . 